"Certain regulatory and efficiency issues of public utility companies in Budapest"

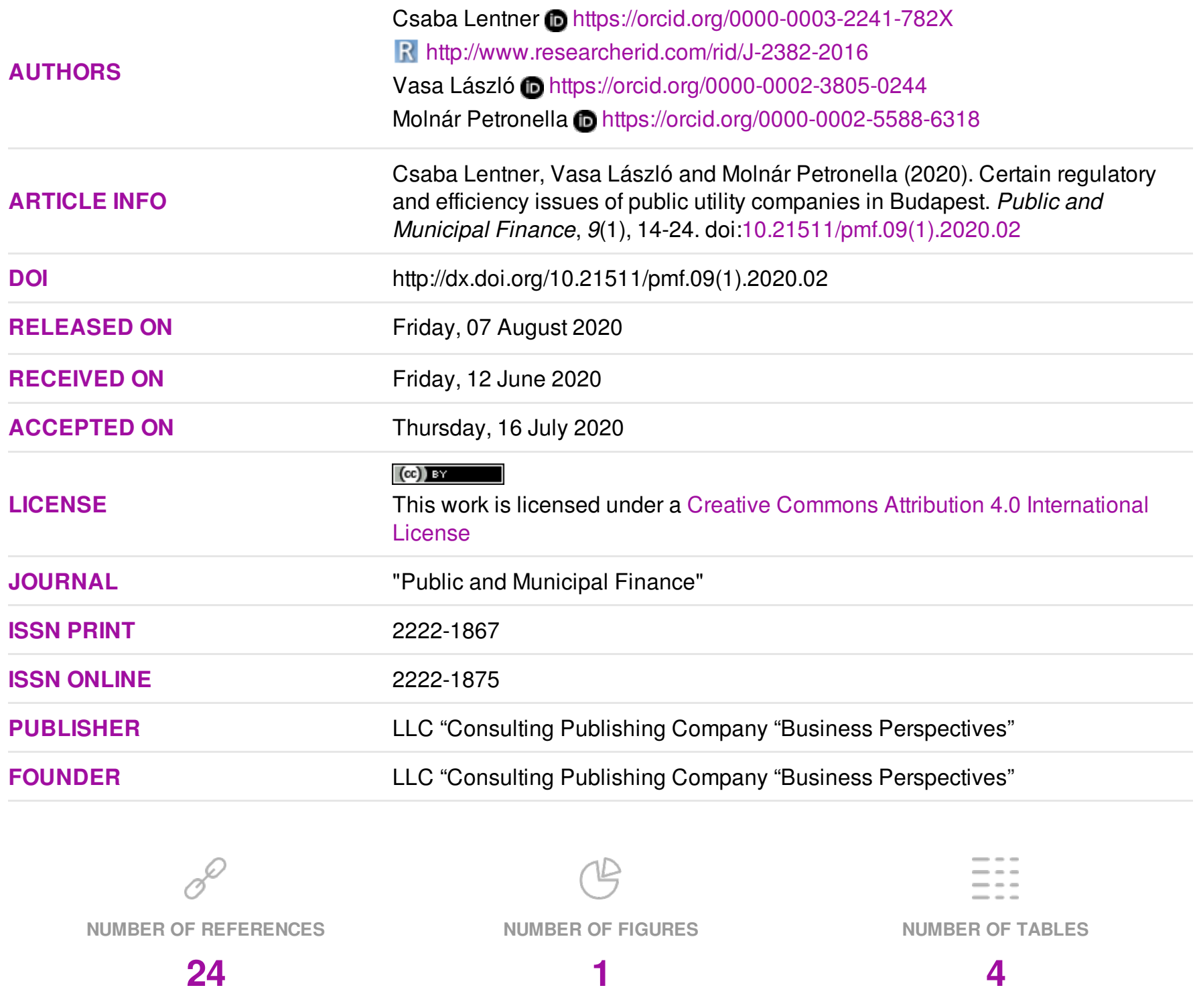

(c) The author(s) 2021. This publication is an open access article. 


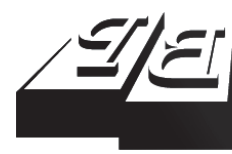

\section{BUSINESS PERSPECTIVES}

(O)

LLC "CPC "Business Perspectives" Hryhorii Skovoroda lane, 10 Sumy, 40022, Ukraine www.businessperspectives.org

Received on: $12^{\text {th }}$ of June, 2020 Accepted on: $16^{\text {th }}$ of July, 2020 Published on: $7^{\text {th }}$ of August, 2020

(C) Csaba Lentner, Vasa László, Molnár Petronella, 2020

Csaba Lentner, Doctor of Public Finance, Professor, National University of Public Service, Budapest, Hungary.

Vasa László, Doctor of Economics, Professor, Széchenyi István University, Győr, Hungary. (Correspondent author)

Molnár Petronella, Researcher, Nationa University of Public Service, Budapest, Hungary.

\title{
CERTAIN REGULATORY AND EFFICIENCY ISSUES OF PUBLIC UTILITY COMPANIES IN BUDAPEST
}

\begin{abstract}
Capital cities of the world are usually characterized by a concentration of the majority of the population and most of the public administration and economic life. Therefore, the efficiency and quality of public service delivery in their administrative territories make a difference. The study examines public service companies in Budapest, Hungary's capital, with the focus on their sectors of activity to describe their system, which may provide good foundations for a prospective international comparison.

This study explores sector-oriented reports of state- and municipally-owned public utility companies providing services within the administrative territory of Budapest and evaluates them in terms of total assets, finance, profitability and efficiency. The study looked for an answer to the question of how the tighter state regulation and control adopted after 2010 affected their management, and what influence the price regulation of consumer public utility charges, imposed since 2013, had on companies' activities.
\end{abstract}

\section{Keywords}

evaluation, ownership, utilities, price regulation, going concern, profitability

\section{JEL Classification $\quad$ G32, H72, H83}

\section{INTRODUCTION}

Since the late $19^{\text {th }}$ century, public utility companies have played an increasing role in Hungary. Public utility companies are responsible for performing public duties and providing public services that have a financial dimension. After the Austro-Hungarian Compromise of 1867 , a developed state railway network was constructed by obtaining shares in privately-owned companies, and the influencing role of the state also increased in other areas of the market sector. As a result of the nationalization processes carried out after World War II, collective ownership became the norm throughout the Hungarian economy. However, after the adoption of a New Economic Mechanism in 1968, market features also appeared - although only to a minimum extent at public utility companies, but the socialist planned economic system - due to its basic philosophy - prevented the evolution of a genuine market structure. Until the early 1990s, larger, nation-wide public service systems were owned by the state; then privatization took place and earning profit became the primary objective of new owners, which had a negative impact on the financial situation of the population, as the households' opportunities to generate income - owing to continuous austerity measures and fiscal anomalies - were rather hectic and limited in terms of real value, except for the last decade.

After the regime change, the leadership of the economic policy established a system of local governments to carry out duties in accordance with the ideology of the era. Local authorities were responsible for the 
performance of public duties, and for this, the foundations were provided by, to an increasing extent, public utility companies, privatized by then, with supply capacities within their administrative territories, and, to a decreasing extent, by public utility companies remained in their ownership. After 2010, an extensive public finance reform was implemented, the main goal of which was to improve fiscal stability and the quality of life of the population. As a result, the New Public Management and its economic philosophy (Decentralization, Privatization, Management), "building up" in Anglo-Saxon countries since the 1970s and taking root in Hungary after the regime change, were replaced by the provision of public utility services. This practice was aimed at the administrative regulation of public utility charges, the centralization of assets and procedures involved in the provision of services, the re-acquisition of public utility companies into national ownership, and through that, the delivery of public good in a wider circle, instead of/beside profit, came to the fore. As a result of reforms, centralization towards the central budget, re-nationalization and the delivery of public good in the widest possible circle, that is, the new CNPG (Centralization, Nationalization, Public Good) philosophy, were applied to the activities of the general government and its public utility companies to provide public services (Lentner, 2020). However, in this process, the successful development of the democratic state can be promoted by an effective system of local self-government. The system of local self-government should be aimed at effective performance of functions and the provision of quality services to citizens by the authorities (Glushcenko \& Kozhalina, 2019).

\section{LITERATURE REVIEW}

In Hungary, the Fundamental Law, being into force since January 1, 2012, contains provisions on the use of national assets and their efficient management. In addition to the provisions of the Fundamental Law, the structure of national assets, provisions pertaining to asset management contracts, and asset management are governed by the Act on National Assets (Act CXCVI of 2011, hereinafter referred to as the NA Act) (Hungarian legislation (Act CXCVI), 2011b). The legislation points out that national assets shall be used exclusively to carry out public duties. The Fundamental Law also provides that economic organizations of the state and local governments shall perform their public duties autonomously and lawfully, keeping expediency and efficiency in view. The operation of stateowned public utility companies is also governed by the NA Act, while the business management of municipally-owned business associations is governed by Act CLXXXIX of 2011 on the local governments of Hungary (hereinafter referred to as the LG Act) (Hungarian legislation (Act CLXXXIX), 2011).

Until 2011, the regulation of public utility companies was less stringent, and as a result, a considerable increase could be witnessed in the number of such companies, which came to a halt in 2011. Since 2011, tighter control has been imposed upon public utility companies, which contributes to implementing good governance and more efficient management of public assets. A more robust regulatory and control environment became necessary, since the reports published by the State Audit Office had revealed the shortcomings in the management of public utility companies and their inadequate asset records. The Stability Act (Act CXCIV of 2011a) contains provisions on the permit obligation of borrowing by municipally-owned corporations, and the powers of the State Audit Office have been extended over the business management of public utility companies (Hungarian legislation (Act CXCIV), 2011a). This is a significant change in regulation, since local governments, demonstrating lax fiscal discipline and taking on excessive liabilities used to exercise a high objectionable proprietor's audit control over their public utility companies, and the debt transfer transactions between local governments and their public utility companies, lacking any substantial external control opportunities on the corporate side until 2011, faced a number of criticisms. Hungarian rules and regulations, however, had to rectify several shortcomings, since for a long time there was no legislation on the internal control systems of state-owned business associations, which could have a positive impact on the efficiency 
of business management. On January 1, 2020, Government Decree No. 339/2019. (XII.23.) entered into force, which set out rules pertaining to the internal control system of publiclyowned business associations. The provisions of the Government Decree shall be applied to all publicly owned business associations from July 1, 2020. Ensuring compliance is important also in the case of state-owned business associations (Boros, 2019), as adequate rules and regulations promote effective business management. Besides, the effectiveness of corporate operations can be improved by continuous control in the case of municipally-owned corporations (Boros \& Fogarassy, 2019), and the requirement to establish internal control channels results in a further increase in the standard of business management. I. Makarenko, Bychenko, S. Makarenko, and Qasimova (2018) examined the corporate social responsibility of public utility companies and found that the implementation of public administrative reforms, increasing the transparency of state-owned companies, determined the reasonability of developing a social responsibility mechanism.

The operation and business management of public utility companies, however, were greatly influenced by the administrative price regulation, introduced in 2013 ("utility cost reductions"). As a result of the regulation, prices for supplies of electricity, natural gas and district heating to household customers were reduced in the first round, followed by prices for supplies of water, waste management and chimney sweeping public services. "Utility cost reductions" manifested themselves in cutting fees chargeable to consumers by 20-25 per cent, which also affected the net revenues of corporations. On the one hand, net revenues have had a "breaking" effect, and, on the other hand, an effect that compelled more reasonable business management. Public transport, one of the most important public service activities, was not concerned by the administrative price regulation, therefore, its analysis is not in the focus of this study. In the European context, after utility cost reductions, Hungarian families pay the least for the supply of gas and electricity. As a result of the administrative price regulation, the number of arrears of customers decreased, as did the amounts of outstanding debts. Following the decline in consumer prices of energy supply, Hungarian households saved approximately HUF 85,000 annually, while reductions in water and sewerage supply, waste management, chimney sweeping and $\mathrm{PB}$ gas charges mean approximately HUF 100,000 (EUR 300-350) on an annual basis (Lentner, 2015).

Utility cost reductions have had a positive impact on the population's income; however, to offset missed revenues, utility service providers must keep cost-effective business management even more to compensate for efficiency and liquidity perspectives resulting from lost revenues. The current study exposes this subject.

Public utility companies manage public assets, therefore their cost-effective and profitable operation is particularly important. After the 2008 crisis, public utility companies were also threatened by excessive indebtedness and factors impeding their efficient operation and operational risks (Hegedüs \& Zéman, 2016). In addition to the crisis, the operation of public utility companies was greatly affected by the state reform launched after 2010 and the administrative price regulation introduced within that framework in 2013. In recent years, the implementation of the accounting principle of going concern has come to the fore in the operation of all businesses (Zéman \& Lentner, 2018). International studies have examined the contents of auditor's reports, the implementation of the accounting principle of going concern during the crisis (Carson, Fargher, Geiger, Lennox, Raghunandan, \& Willekens, 2013; Marshall, Raghunandan, \& Riccardi, 2014; Read \& Yezegel, 2018). In the case of public utility companies (as well), the implementation of the fundamental principle is expected at all times, as they finance the performance of their public duties from public assets. It is essential to observe how the criteria of responsible corporate governance are applied during the operation of these corporations. The examination of the future operability of public utility companies is of key importance because the termination of their activities can have an adverse impact on the society as a whole, and can cause a decline in the standard of living and quality of life of the population. Operability is influenced by the fact that these corporations are affected by not only market conditions, but, to a 
greater extent, by economic policy measures, the changes in the political environment and legislation, and, in recent months (early 2020), the spread of massive health issues, "demanding" the continuous provision of public services even more harshly, and uninterrupted public services are expected as a subjective, citizen's right, even despite work stoppages at many manufacturing and service providing market enterprises and the quarantining and lockdown of the workforce.

Figure 1 illustrates what factors may be indicators of inoperability and when the implementation of the accounting principle of going concern can be questioned.

This empirical study examines the impact of extensive public finance reforms on the operability of public utility companies concerned by the utility cost reductions in Budapest. From the perspective of this research, it is noted that it focused on state- and municipally-owned public utility com- panies. Public utility companies have undergone several changes over the years.

Companies engaged in electricity and natural gas supply are state-owned ones. (Companies examined included Budapesti Elektromos Müvek Nyrt, and Főgáz Kft.) Nemzeti Közmüvek Zrt. has a 100 per cent stake in the natural gas supplier. From the perspective of the current examination, there is another company, in which Nemzeti Közmüvek Zrt. has a 100 per cent stake; it is an electric public utility company with a registered office in Szeged, therefore it was not examined. A water public utility company and a district heating company examined are municipally owned. (Companies examined included Fővárosi Vízművek Zrt. and Főtáv Zrt.) The company engaged in waste management examined (FKF Nonprofit Zrt.) is municipally owned, but it was registered in 2016 as a company in which Magyar Nemzeti Vagyonkezelö Zrt. had a 100 per cent stake. Since the operation of this

Source: Developed based on Lentner (2015, p. 766).
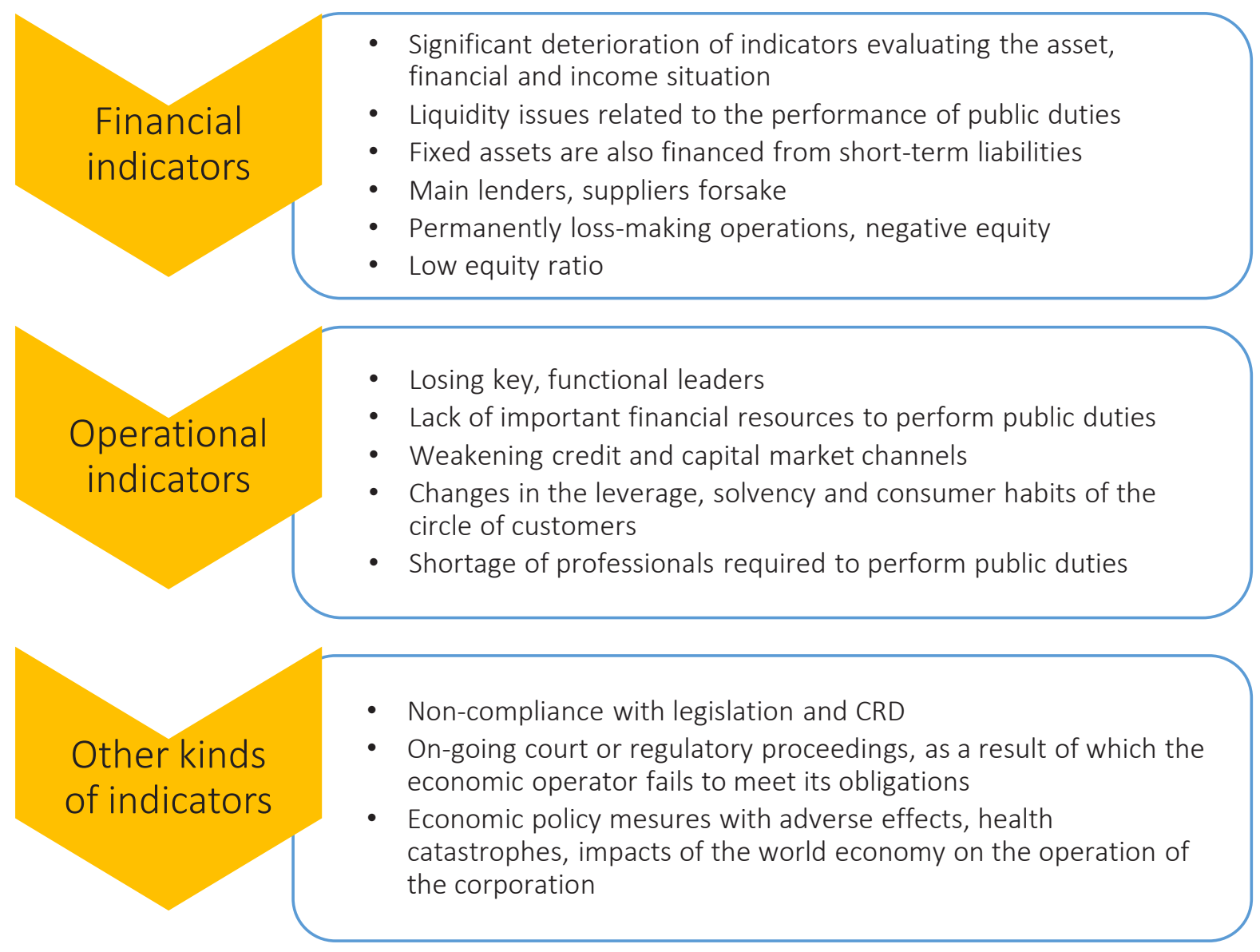

Figure 1. Indicators of operational difficulties 
state-owned company did not encompass the whole of the examined period, it was not analyzed. Van der Waldt, Fourie, Jordaan, and Chitiga-Mabugu (2018) reveal that the provision of four basic services, i.e. waste management, water and wastewater management and electric supply, is jeopardized if local governments lack technical knowledge.

\section{METHODS}

The subject matter of the analysis is the business management of public utility companies that operate in Budapest, have their registered office in Budapest and are engaged in different sectors (district heating, natural gas, electricity, water and sewerage sectors). This study involved public utility companies in the operation of which the administrative price regulation had a crucial role. This study sought the answer to the question of how a more stringent regulation and control system and the administrative price regulation influenced the business management of public utility companies, and how the principle of going concern was implemented at the corporations examined. That is, the study was aimed at justifying, in terms of accounting, how the public utility service providers engaged in the sectors concerned could offset the "breaking" of net revenues, an inevitable consequence of the utility cost reductions, by the more robust regulatory and control system applicable to them, and, as an illustration of that, how their efficiency indicators changed. The study was based on publicly available reports of five state- or municipally-owned public utility companies; also, indicators illustrating their business management were constructed. The indicators refer to the wealth, the asset, financial, efficiency and income situation of the business associations. Electric and gas supply companies examined are state-owned, while companies engaged in the district heating, water or waste sectors are municipally owned. The criteria for selecting public utility companies to be included in the research were their continuous operation in Budapest, their registered office in the capital, and the sample in Budapest itself, that is, the size of companies and sectors, and that of the circle of customers that they serve, which provides a basis for drawing wide-ranging conclusions.

\section{RESULTS}

\subsection{The implementation of the principle of going concern at public utility companies in Budapest}

Table 1 shows liquidity indicators of the studied corporations in relation to 2011, 2015 and 2018. The reason for choosing these years for study is that the process of local governments' debt consolidation began in 2011 and finished until 2014 (Lentner, 2014), and most public finance reforms were realized in this period. Therefore, one can get an idea of the 2015 study of how the economic environment of corporations providing public services in the territory of the municipality of Budapest changed as a result of a tightening regulatory environment, and also the impact of the administrative price regulation introduced in 2013 could be felt in the year 2015. The year 2018 is the last period completed with a report at the time of this writing. The time frame of the analysis spans almost ten years, which is the adequately long period for concluding.

Table 1. Changes in the financial situation of corporations examined in 2011, 2015 and 2018 (data are in numerical values)

Source: Own edition

\begin{tabular}{|c|c|c|c|c|c|c|}
\hline \multirow{2}{*}{$\begin{array}{c}\text { Indicator } \\
\text { Sector/Years } \\
\text { examined }\end{array}$} & \multicolumn{3}{|c|}{ Current ratio } & \multicolumn{3}{|c|}{ Acid test ratio } \\
\hline & 2011 & 2015 & 2018 & 2011 & 2015 & 2018 \\
\hline $\begin{array}{l}\text { District heating } \\
\text { service provider }\end{array}$ & 1.324 & 2.750 & 1.027 & 1.294 & 2.640 & 1.002 \\
\hline $\begin{array}{l}\text { Natural gas } \\
\text { supplier }\end{array}$ & 0.960 & 1.803 & 0.749 & 0.929 & 1.725 & 0.681 \\
\hline $\begin{array}{l}\text { Electric service } \\
\text { provider }\end{array}$ & 0.993 & 0.976 & 8.071 & 0.967 & 0.928 & 7.718 \\
\hline Water utilities & 1.207 & 1.248 & 1.656 & 1.166 & 1.111 & 1.552 \\
\hline $\begin{array}{l}\text { Waste } \\
\text { management } \\
\text { service provider }\end{array}$ & 1.767 & 2.684 & 1.853 & 1.598 & 2.262 & 1.619 \\
\hline
\end{tabular}

When assessing the financial situation of enterprises, their liquidity indicators should be examined. The value of a liquidity indicator is acceptable if it exceeds 1.3, and it can be considered particularly good in terms of solvency if its value is around 1,8 . The acid test ratio disregards the least 
Table 2. Changes in the asset situation of corporations examined in 2011, 2015 and 2018 (data are in numerical values)

Source: Own edition.

\begin{tabular}{|c|c|c|c|c|c|c|}
\hline \multirow{2}{*}{$\begin{array}{c}\text { Indicator } \\
\text { Sector/Years examined }\end{array}$} & \multicolumn{3}{|c|}{ Equity ratio } & \multicolumn{3}{|c|}{ Liabilities to assets (L/A) ratio } \\
\hline & 2011 & 2015 & 2018 & 2011 & 2015 & 2018 \\
\hline District heating service provider & 63.94 & 60.77 & 50.91 & 25.40 & 13.53 & 23.99 \\
\hline Natural gas supplier & 63.90 & 71.83 & 67.50 & 20.56 & 9.55 & 17.81 \\
\hline Electric service provider & 63.50 & 68.38 & 70.66 & 36.50 & 27.08 & 29.34 \\
\hline Water utilities & 73.64 & 10.11 & 13.31 & 6.68 & 86.65 & 83.58 \\
\hline Waste management service provider & 58.67 & 63.14 & 52.76 & 22.44 & 9.47 & 18.54 \\
\hline
\end{tabular}

liquid current assets (value for inventories) ${ }^{1}$, and the value of the indicator thereby obtained is acceptable if it is above 1 (Zéman \& Béhm, 2016).

The first thing one can notice about the data of Table 1 is that the solvency of corporations engaged in district heating services, natural gas supply and waste management services was the most favorable in 2015 , the values of the indicators were the highest in this year during the period examined. In the case of an electric service provider and water utility companies, continuous improvement in the values of indicators can be observed, and while the indicators of the electric service provider had increased significantly by 2018 , only a moderate increase at the water utility company was observed. Given the limit value (that is, the liquidity indicator of a business association can be regarded as outstanding if it exceeds the value of 1.8), only the waste management service provider can boast of an outstanding financial position. In the case of the electric service provider, even the outstanding results of 2018 do not necessarily indicate a favorable business management situation, as the high value of the liquidity indicator may lead to a fall in profitability in the long term. As this analysis focused on the trend of liquidity, no in-depth examinations were carried out in this field. It is noted that the fact that the state prescribes a 20 25 per cent reduction of consumer prices did not automatically result in a drop of the same volume in revenues, because of, on the one hand, the moderation and mobilization of debts regarded as bad ones earlier, a stronger solvent consumer's demand, and on the other hand, direct and indirect "compensating" subsidies - distorting mar- ket conditions - provided by the state in certain cases; these items have not been examined in this study.

Table 2 shows how the indicators illustrating the capital structure of corporations examined changed.

It is important that the equity ratio should be above 50 per cent, because in this case, the value of a company's equity exceeds the value of its liabilities. In the case of the water utility company, the assets situation demonstrated a marked deterioration in 2015 and 2018. Such a drop in the equity ratio may lead to the impossibility of effective business management. The indicators of companies providing district heating, natural gas, electric and waste management services show a stable capital basis.

Short-term liabilities account for the majority of liabilities of companies, except for the value of the water utility company in 2015 and 2018, since in this period the value of the company's long-term liabilities increased, and there was a growth in investment and development loans. In 2015, the companies providing district heating, natural gas, electric and waste management services had low levels of debt, as well as adequate solvency; however, by 2018, the liabilities to assets (L/A) ratio of all four companies increased. After examining the equity ratio and the liabilities to assets (L/A) ratio, the overall conclusion is that apart from the water utility company, the asset situation of public utility companies was stable in the period examined.

In addition to examining the financial and asset situation of corporations, their profitability and efficiency positions were also assessed (Table 3).

1 As for the statistical indicators used in the analysis, this study was aimed at relevance and mapping the main directions of changes, therefore, for example, the simplest approaches of the many ways of calculating liquidity were adopted. Consequently, the categories of frozen inventories and bad debts were not considered when determining current assets included in the numerator. 
Table 3. Changes in the profitability and efficiency of corporations examined in 2011, 2015 and 2018 (data are in numerical values)

Source: Own edition.

\begin{tabular}{|c|c|c|c|c|c|c|c|c|c|}
\hline \multirow{2}{*}{$\frac{\text { Indicator }}{\text { Sector/Years examined }}$} & \multicolumn{3}{|c|}{ Return on assets } & \multicolumn{3}{|c|}{ Return on sales } & \multicolumn{3}{|c|}{ After-tax return on sales } \\
\hline & 2011 & 2015 & 2018 & 2011 & 2015 & 2018 & 2011 & 2015 & 2018 \\
\hline District heating service provider & $2.9 \%$ & $1.0 \%$ & $1.0 \%$ & $5.0 \%$ & $4.9 \%$ & $1.1 \%$ & $2.8 \%$ & $1.1 \%$ & $1.4 \%$ \\
\hline Natural gas supplier & $12.6 \%$ & $3.6 \%$ & $5.9 \%$ & $22.4 \%$ & $12.4 \%$ & $18.4 \%$ & $18.4 \%$ & $5.9 \%$ & $11.9 \%$ \\
\hline Electric service provider & $8.9 \%$ & $6.2 \%$ & $6.0 \%$ & $9.6 \%$ & $13.5 \%$ & $11.1 \%$ & $7.6 \%$ & $7.5 \%$ & $6.8 \%$ \\
\hline Water utilities & $1.4 \%$ & $0.7 \%$ & $0.4 \%$ & $4.1 \%$ & $3.9 \%$ & $1.9 \%$ & $5.0 \%$ & $2.0 \%$ & $1.4 \%$ \\
\hline Waste management service provider & $4.0 \%$ & $0.6 \%$ & $-0.4 \%$ & $6.4 \%$ & $5.1 \%$ & $0.8 \%$ & $3.7 \%$ & $0.6 \%$ & $-0.6 \%$ \\
\hline
\end{tabular}

When examining playability and corporate efficiency, the study focused on the companies' Return on Assets (ROA), Return on Sales and After-Tax Return on Sales indicators. In their assessment, the indicators are expected to be positive, and their growth suggests stable profitability. This criterion was not satisfied by the waste management service provider in 2018, and the values of the indicators were negative as a result of loss-making business management. Except the natural gas supplier, the values of the profitability indicator (ROA) and the efficiency indicators (Return on Sales, After-Tax Return on Sales) dropped at all examined corporations in 2018 compared to the previous period.

In addition to changes in profitability and corporate efficiency, the changes in figures influencing them should be noted, that is, the changes in profit (loss) after tax and the net revenues of sales compared to the previous year examined (compared to the year 2011 in the year 2015 and to the year 2015 in the year 2018, see Table 4). For instance, the profit (loss) after tax decreased by 63.613 per cent, while revenues dropped by 23.786 per cent at the district heating company in 2015 compared to the 2011 data. By 2018, a 17.986 per cent rise can be seen compared to 2015.
While business management of corporations generally improved in 2015 based on liquidity, financial and profitability indicators, their profit (loss) after tax value and net revenues significantly dropped. The largest decline can be seen in the profit (loss) of the waste management company in the current year when the value turned into the negative range in 2018. From the perspective of efficiency, the water utility company and the waste management company delivered the weakest performance in the period examined. Since the declining tendency of profit (loss) after tax and profitability indicators sooner or later also produce effects that weaken liquidity, it is expedient to improve payability in critical sectors. Overall, the entire circle of public utility companies can be characterized by a drop in their profit (loss) after tax due to a reduction in their net revenues typically (and mostly) by around 25 per cent as a result of the administrative price regulation. However, their liquidity, capitalization and profitability indicators did not demonstrate such a decline, which suggests more efficient management of their resources and more stringent control of their business management processes. Public utility companies are capable of maintaining their

Table 4. Changes in profit (loss) after tax and net revenues of corporations examined in 2011, 2015 and 2018 (data are in percentages)

Source: Own edition.

\begin{tabular}{|c|c|c|c|c|c|c|}
\hline \multirow{2}{*}{$\begin{array}{c}\text { Indicator } \\
\text { Sector/Years examined }\end{array}$} & \multicolumn{3}{|c|}{$\begin{array}{c}\text { Changes in profit (loss) after tax, } \\
\text { change in percentages compared to } \\
\text { the previous year examined }\end{array}$} & \multicolumn{3}{|c|}{$\begin{array}{c}\text { Changes in net revenues, change } \\
\text { in percentages compared to the previous } \\
\text { year examined }\end{array}$} \\
\hline & 2011 & 2015 & 2018 & 2011 & 2015 & 2018 \\
\hline District heating service provider & - & -63.613 & 17.986 & - & -23.786 & 7.180 \\
\hline Natural gas supplier & - & -74.642 & 91.178 & - & -22.184 & -7.424 \\
\hline Electric service provider & - & -23.230 & 5.802 & - & -22.324 & 15.451 \\
\hline Water utilities & - & -42.563 & -33.252 & - & 43.871 & -7.657 \\
\hline Waste management service provider & - & -86.208 & -178.512 & - & -10.530 & -6.373 \\
\hline
\end{tabular}


business management, implementing the principle of going concern. At the same time, lower consumer prices, aimed at reducing the utility cost, also prevail and are better suited to the spending power of the population. Public utility companies are able to provide public services more efficiently than before across an economic and, more importantly, a social dimension, as a result of public finance reforms and, as a part of them, the introduction of the administrative price regulation. However, there are further potential opportunities for a positive shift, and it is even expedient to further improve the standard of their business management.

\subsection{Special legal order caused by the epidemic affecting the operation of business associations}

The capacities of public utility companies to provide public services are greatly affected by the "spill-overs" from the national economic policy space, its events and the world economy. Escalating health and epidemiological problems can be defined as a new type of risks. Despite the adverse economic impact of the pandemic (stoppage of production in the market sector, temporarily distancing the workforce from workplaces), expanding since early 2020, the uninterrupted provision of public services in terms of the operation of the state and society is expected,. The continued operations of companies providing public services in the territory of Budapest, the epidemiological situation, and the authorities' response to it add extra weight to the importance of implementing the accounting principle of going concern, as an accounting-management requirement to maintain continued operations.

The Hungarian government declared a state of emergency in the entire territory of Hungary on March 11, 2020, to offset the consequences of the human epidemic causing mass illness and threatening the safety of property, and to protect the health and life of Hungarian citizens (Legislation of the European Union, 2020). The pandemic has significantly shaken both the world economy and the business manage- ment of companies. Business associations have faced suddenly occurring liquidity problems, which may lead to an operational paralysis in the long term. Therefore, the government has implemented several economic policy measures for the sake of corporations struggling with financial difficulties (Government Resolution No. $1109 / 2020,2020)$. Such interventions are immediate measures taken to mitigate the effects of the COVID-19 pandemic on the national economy, including an exemption from social contribution tax in specific sectors (such as catering, sport and entertainment, leisure activities, television program production, etc.) and the introduction of a payment moratorium (Ministry of Justice of Hungary, 2020, March 23). (At the time of this writing, the payment moratorium did not include arrears on public utility bills see Ministry of Justice of Hungary (2020, March 24)). These measures have also had an impact on the operation of public utility companies, and the government has established professional support for the performance of functions by state-owned and non-state-owned companies that are vital for the operation of the state in a state of emergency (Legislation of the European Union, 2020, March 20). According to a communication from the Ministry of Defence, on March 19, 2020, Hungarian Defence Force management groups started to work at 71 enterprises (and their number increased to 84 on March 25, 2020) (Hungarian legislation (Act CLXXXIX), 2011), that is, their task was to promote the safe and uninterrupted operation of vital Hungarian business associations. This measure affected several state- and municipally-owned corporations as well. These corporations, performing public duties, where the management groups of the Hungarian Defence Forces have appeared, include corporations engaged in water and sewer services, waste management services, electricity and natural gas supply, passenger transport and media services. Against this background, one can conclude that the observance of the accounting principle of going concern, and, in terms of its consequences, continued operations at public utility companies (including the corporations operating in Budapest and being the focus of this study) can be promoted by the legal instruments of the state, which are identified as a new type of instrument to maintain continuous operations. 


\section{CONCLUSION}

This research focused on business operations of public utility companies in 2011, 2015 and 2018. The examined corporations operated in different sectors. Consequently, information was obtained on the business management, asset, financial and income situation of a district heating company, a natural gas supplier, an energy supplier, a water utility company and a waste management service provider from their reports. The significance of the study is that serious social problems may occur if a public utility company ceases its operations or the provision of public services becomes interrupted (unpredictable, and of a declining quality), which should be avoided in a welfare society built on democratic relations. Thus, the analysis of changes affecting the operations of public utility companies has a social usefulness dimension.

When creating the scope of the examination, the study considered, due to the characteristic features of Budapest, significant supply capacities and the dominant nature of the circle of customers, as well as the fact that the services of these sectors have been concerned by the administrative price regulation since 2013. The analysis reveals that by 2015 - because of the administrative price regulation - there was a fall in the profit (loss) and net revenues of all corporations. However, despite this decline, changes in efficiency indicators built on the basis of these reports did not suggest such an obvious negative shift as compared to the corporate performance indicators (profit or loss after tax, revenues), even some areas showed improvement by 2018 thanks to more disciplined and controlled business management. Overall, despite a drop in net revenues and profit (loss) after tax, public utility companies have preserved their operability alongside the implementation of the accounting principle of going concern. The previous (2016) concept of the State Audit Office has been justified by this research, since it was verified that there was a shift towards a more disciplined business management and control system, which could largely offset the fall in net revenues, caused by the administrative price regulation, in the field of efficiency. It is concluded that continuous business management, keeping the reductions of cost in view, could not have been implemented simultaneously without extensive public finance reforms. That is, more stringent statutory regulations and greater proprietor's control have contributed to the more effective business management of public utility companies. Given the financial, operational and other emergency indicators included in the study, it is concluded that public utility services are special service activities that are expected to be maintained (or on a specific level) even in the most critical situations by the general government units.

\section{AUTHOR CONTRIBUTIONS}

Conceptualization: Csaba Lentner.

Data curation: Vasa László, Csaba Lentner.

Formal analysis: Vasa László, Molnár Petronella.

Funding acquisition: Csaba Lentner.

Investigation: Vasa László, Molnár Petronella.

Methodology: Vasa László, Molnár Petronella.

Project administration: Molnár Petronella.

Resources: Vasa László.

Software: Molnár Petronella.

Supervision: Vasa László, Molnár Petronella.

Validation: Vasa László, Csaba Lentner, Molnár Petronella.

Visualization: Vasa László, Csaba Lentner, Molnár Petronella.

Writing - original draft: Csaba Lentner, Molnár Petronella.

Writing - review \& editing: Csaba Lentner, Molnár Petronella. 


\section{REFERENCES}

1. Boros, A. (2019). Compliance Audit Issues of State-owned Business Associations. Public Finance Quarterly, 64(4), 542-558. https:// doi.org/10.35551/PFQ_2019_4_6

2. Boros, A., \& Fogarassy, Cs. (2019). Relationship between Corporate Sustainability and Compliance with State-Owned Enterprises in Central-Europe: A Case Study from Hungary. Sustainability, 11(20), 5653. https://doi. org/10.3390/su11205653

3. Carson, E., Fargher, N. L, Geiger, M. A., Lennox, C. S., Raghunandan, K., \& Willekens, M. (2013). Audit Reporting for GoingConcern Uncertainty: A Research Synthesis. Auditing: A Journal of Practice \& Theory, 32(1), 353-384. https://doi.org/10.2308/ajpt-50324

4. Glushchenko, J., \& Kozhalina, N. (2019). Development Trends of Local Taxes in the System of Local Budgets in Ukraine. Public and Municipal Finance, 89(1), 104111. http://dx.doi.org/10.21511/ pmf.08(1).2019.09

5. Government Resolution 1109/2020. (2020, March 18). 1109/2020 (III. 18.) Kormányhatározat, az ország müködéséhez szükséges létfontosságú állami és nem állami gazdasági társaságok veszélyhelyzeti feladat-ellátásának szakmai támogatásáról [Government Resolution 1109/2020 (III. 18.) on the Professional Support for the Emergency Operation of Certain State-Owned and Private Companies of Strategic Importance]. Retrieved from https://net.jogtar. hu/jogszabaly?docid=A20H1109. KOR

6. Hegedűs, Sz., \& Zéman, Z. (2016). Tőkeszerkezeti elméletek érvényesülésének vizsgálata a hazai önkormányzati tulajdonú gazdasági társaságok körében [Prevalence of Capital Structure Theories among Municipal Companies]. Statisztikai Szemle - Statistical Review, 94(10), 1032-1049. (In Hungarian). http://dx.doi.org/10.20311/ stat2016.10.hu1032

7. Hungarian legislation (Act CLXXXIX). (2011). évi CLXXXIX törvény. Magyarország helyi önkormányzatairól [Act CLXXXIX of 2011 on the local governments of Hungary]. Retrieved from https://obvf.hu/wp-content/uploads/2016/04/2011_evi_clxxxix_ torveny.pdf

8. Hungarian legislation (Act CXCIV). (2011a). évi CXCIV törvény. Magyarország gazdasági stabilitásáról [Act CXCIV of 2011 on the Economic Stability of Hungary]. Retrieved from https:// www.mnb.hu/letoltes/2011-evicxciv-tv.pdf

9. Hungarian legislation (Act CXCVI). (2011b). évi CXCVI törvény a nemzeti vagyonról [Act CXCVI of 2011on National Assets]. Retrieved from https://net.jogtar.hu/ jogszabaly?docid=a1100196.tv

10. Hungarian legislation (Act CXXVIII). (2011c). évi CXXVIII törvény a katasztrófavédelemről és a hozzá kapcsolódó egyes törvények módosításáról [Act CXXVII of 2011 Concerning disaster management and amending certain related acts]. Retrieved from http://www.fao. org/faolex/results/details/en/cl LEX-FAOC129205/

11. Legislation of the European Union. (2020, March 20). COMMUNICATION FROM THE COMMISSION Temporary Framework for State Aid Measures to Support the Economy in the Current COVID-19 Outbreak (2020/C91 I/01). Official Journal of the European Union, CI 91/1. Retrieved from https://eur-lex.europa.eu/legalcontent/EN/TXT/?uri=OJ\%3AJO C_2020_091_I_0001

12. Lentner, Cs. (2014). The Debt Consolidation of Hungarian Local Governments. Public Finance Quarterly, 59(3), 310-325. Retrieved from https://asz.hu/ storage/files/files/public-financequarterly-articles/2014/a_lentnercs_2014_3.pdf?download=true

13. Lentner, Cs. (2015). A vállalkozás folytatása számviteli alapelvének érvényesülése közüzemi szolgáltatóknál és költségvetési rend szerint gazdálkodóknál - magyar, európai jogi és eszmetörténeti vonatkozásokkal: 31. fejezet [Enforcement of thePrinciple of Going Concern with Special Regard to Public Service Providers - with Hungarian, European Legal and Historical Aspects, Chapter 31.], In Csaba Lentner (Ed.), Adózási pénzügytan és államháztartási gazdálkodás: Közpénzügyek és Államháztartástan II. [TaxFinance and Public Finance Management: Public Finance and Public Management II] (pp. 763-783). Budapest, Magyarország: Nemzeti Közszolgálati és Tankönyv Kiadó Zrt. (In Hungarian). Retrieved from https://www.researchgate.net/ publication/312490035_A_vallalkozas_folytatasa_szamviteli_alapelvenek_ervenyesulese_kozuzemi_szolgaltatoknal_es_koltsegvetesi_rend_szerint_gazdalkodoknal_-_magyar_europai_jogi_ es_eszmetorteneti_vonatkozasokkal

14. Lentner, Cs. (2020). East of Europe, West of Asia (Chapter II, IV). L'Harmattan Publishing, Paris Retrieved from https://www.researchgate.net/ publication/341598141_East_ of_Europe_West_of_Asia_Historical_Development_of_Hungarian_Public_Finances_from_the_ Age_of_Dualism_to_the_Present

15. Makarenko, I., Bychenko, D., Makarenko, S., \& Qasimova, G. (2018). Environmental Responsibility Mechanism Development in the Public Sector of the Economy. Environmental Economics, 9(3), 28-41. http://dx.doi.org/10.21511/ ee.09(3).2018.04

16. Marshall, A. G., Raghunandan, K., \& Riccardi, W. (2014). The Global Financial Crisis: U.S. Bankruptcies and Going-Concern Audit Opinions. Accounting Horizons, 28(1), 59-75. https://doi.org/10.2308/ acch-50659

17. Ministry of Justice of Hungary. (2019, December 13). The Fundamental Law of Hungary. Retrieved from https://njt.hu/translated/ doc/TheFundamentalLawofHungary_20191213_FIN.pdf 
18. Ministry of Justice Hungary. (2020, March 11). Government Decree 40/2020 (11 March) on the Declaration of State of Danger. Retrieved from https://njt.hu/translated/doc/ J2020R0040K_20200326_FIN.pdf

19. Ministry of Justice Hungary. (2020, March 23). Government Decree 61/2020 (23March) on Detailed Rules Concerning Public Dues of Government Decree 47/2020(18 March) on Immediate Measures Necessary for Alleviating the Effects of the Coronavirus Pandemic on National Economy, and on Certain New Measures]. Retrieved from https://njt.hu/translated/doc/ J2020R0061K_20200411_FIN.pdf

20. Ministry of Justice Hungary. (2020, March 24). Government Decree 62/2020 (24March) on Detailed Rules Concerning Payment Moratorium of Government Decree 47/2020 (18March) on
Immediate Measures Necessary for Alleviating the Effects of the Coronavirus Pandemic on $\mathrm{Na}$ tional Economy. Retrieved from https://njt.hu/translated/doc/ J2020R0062K_20200325_FIN.pdf

21. Read, W. J., \& Yezegel, A. (2018). Going-Concern Opinion Decisions on Bankrupt Clients: Evidence of Long Lasting Auditor Conservatism? Advances in Accounting, 40, 20-26. https://doi. org/10.1016/j.adiac.2017.12.004

22. Van der Waldt, G., Fourie, D., Jordaan, J., \& Chitiga-Mabugu, M. (2018). Skills Profile of Technical Staff in the South African Local Government Sector: an Empirical Survey. Problems and Perspectives in Management, 16(1), 173-185. http://dx.doi.org/10.21511/ ppm.16(1).2018.17

23. Zéman, Z., \& Béhm, I. (2016). A pénzügyi menedzsment controll el- emzési eszköztára [Financial management control analysis toolkit] (396 p.). Budapest, Magyarország: Akadémiai Kiadó. (In Hungarian). Retrieved from https://saldokiado. hu/assets/res/download/a-penzugyi-menedzsment-controllelemzesi-eszkoztara.pdf

24. Zéman, Z., \& Lentner, Cs. (2018). The Changing Role of Going Concern Assumption Supporting Management Decisions after Financial Crisis. Polish Journal of Management Studies, 18(1), 441-454. Retrieved from https://www.researchgate.net/ publication/330193448_THE_ CHANGING_ROLE_OF_GOING_CONCERN_ASSUMPTION_SUPPORTING_MANAGEMENT_DECISIONS_AFTER_FINANCIAL_CRISIS_THE_POLISH_JOURNAL_OF MANAGEMENT_STUDIES 